\title{
THE CONSTITUTIONALISATION OF CRIMINAL STANDARDS CONCERNING THE EXERCISE OF THE LAWYER'S PROFESSION
}

DOI: $10.47743 /$ rdc-2019-2-0004

Elena Cătălina TUDURACHI ${ }^{1}$

\section{Abstract}

The analysis of the process of constitutionalising the norms regarding the exercise of the lawyer's profession starts from the date of the adoption of Law no. 51/1995 regarding the exercise of the lawyer's profession, subject to the a priori review of the Constitutional Court. By presenting the decisions pronounced by the Constitutional Court, its role in the constitutionalising the relevant regulations is highlighted, influencing the vision of the Romanian legislator on the legal profession.

Keywords: exception of unconstitutionality; constitutionalising the law; decisions of the Constitutional Court; lawyer's profession

\section{Introduction}

The standards on the exercise of the lawyer's profession comprised in the Law no. 51/1995 have made the object of numerous referrals ${ }^{2}$ of unconstitutionality. If we refer to the provisions within the legislative documents with a preconstitutional character, they were rejected most of the times by arguing that, since the entry into force of the Law no. 51/1995, the provisions in question remained without object ${ }^{3}$.

\footnotetext{
${ }^{1}$ Elena Cătălina Tudurachi, Doctoral Candidate, the Faculty of Law “Alexandru Ioan Cuza”, Iaşi, Romania, avocateva.elena@gmail.com.

2 By the date of writing this paper, the Constitutional Court solved over 100 unconstitutionality referrals, related to the provisions of the Law no. 51/1995.

3 Through the Romanian Constitutional Court's Decision no. 83 of September 20 $0^{\text {th }}, 1995$, the unconstitutionality exception of the provisions of Article 1 para. 2 and Article 2 para. 1 of the Decree-law no. 90/19903 was rejected as clearly unfounded because 'between the date of notifying the Court and the date of settling the exception, the Decree-law no. 90/1990 has been entirely repealed, expressly, through the provisions under Article 79 of the Law no. 51/1995 on the exercise of the lawyer's professions; thus, the exception had no more object. Through the Romanian Constitutional Court's Decision no. 115 of November 15 unconstitutionality exception of the provisions within the Decree no. 281/19543 and within the Decree-law no. 90/1990 was rejected remained without object, given the express repeal occurred upon the entry into force of the Law no. 51/1995. The plaintiff requested through the court actions to have a decision given that would acknowledge the right to exercise the lawyer's profession, without passing the Bar exam. In order to motivate
} 
According to the provisions of Article 29 para. 3 of the Law no. 47/1992 on the organisation and functioning of the Constitutional Court, republished, "the provisions determined as unconstitutional through a previous decision of the Constitutional Court cannot be the object of an exception". Per a contrario, the provisions determined as constitutional can make the object of this control, which means that the same texts previously determined by the Court as constitutional may make the object of a new unconstitutionality exception, pursuant to the same criticism and constitutional grounds or pursuant to different criticism and grounds.

According to the Romanian Constitutional Court's Decision no. 2 of January $11^{\text {th }}$, $2012^{4}$, the Constitutional Court ruled that Article 147 para. 4 of the Romanian Constitution - concerning the general mandatory character of its decisions - "fails to make distinctions by the types of decisions or by the contents of such decisions, which leads to the conclusion that all the decisions of this Court, as a whole, are generally mandatory".

Pursuant to the Romanian Constitutional Court's Decision no. 302 of March $27^{\text {th }}$, $2012^{5}$, the Court acknowledged the following: "if by a Court's decision it is declared the unconstitutionality of a law text, it produces juridical effects erga omnes, a consequence deriving from the uniqueness and independence character of the constitutional jurisdiction authority. If the opposite occurs, the Court's decision - of rejection also has a general mandatory character and it has power only for the future, pursuant to Article 147 para. 4 of the Romanian Constitution, meaning that the public authorities involved in the case where the exception was invoked are forced to respect the decision - both the provision and its underlying grounds - but the juridical effect of such a decision is circumscribed only to the procedural framework of the litigation where the exception was waived, so it has an inter partes character. Therefore, the same text of law may be brought for re-examination before the Constitutional Court, taking into account that new aspects and constitutional grounds may be revealed, which may justify a different solution in the future.

\section{The right to associate and to constitute professional associations}

The provisions of the Law no. 51/1995 have been criticised in numerous cases concerning the creation of parallel forms of association, as well as to the so-called "Romanian Constitutional Bar".

the unconstitutionality exception, it was shown that the legislative documents in question violated the principle stated by Article 38 para. 1 of the Romanian Constitution (Article 41 in the revised Constitution), according to which the right to work cannot be restrained, and the choice of the profession and the workplace are free.

${ }^{4}$ Published in the Official Gazette of Romania no. 131 of February 23rd 2012.

${ }^{5}$ Published in the Official Gazette of Romania no. 361 of May 29th 2012.

\section{CONSTITUTIONAL LAW REVIEW}




\section{The constitutionalisation of criminal standards concerning the exercise...}

According to Article 1 para. 2 and 3 of the Law no. 51/1995, the lawyer's profession must only be exercised by lawyers featured in the table of the Bar to which they belong, while the constitution and functioning of Bars outside the National Association of the Romanian Bars are prohibited ${ }^{6}$. These provisions attest the principle of exercise of the lawyer's profession, which means that it is mainly regulated by the Special Law, the Statute and the European Union Code of Conduct of the lawyers. A lawyer cannot be registered in more than one Bar (Article 3, para. 3 of the Statute). All legally founded Bars in Romania are rightful members of the National Association of the Romanian Bars (UNBR), a legal entity of public interest, founded by the Law and declared as unique successor of the Union of Romanian Lawyers ${ }^{7}$ (Article 1 para. 2 corroborated with Article 59 para. 1, 2, 4 and 5 of the Law no. 51/1995, and with Article 5 para. 2 and 3 of the Statute, respectively).

The need to prevent the emergence and dissemination of parallel lawyer structures led to the legality of Bar constitution and functioning being conditioned by a membership in the National Association of the Romanian Bars ${ }^{8}$. The exercise of the lawyer's profession outside the framework provided by the Law is an offence ${ }^{9}$.

By Decision no. 233 of May $25^{\text {th }}, 2004^{10}$, it was rejected the exception of unconstitutionality of the provisions of Article 48 para. 1 first thesis and Article 57 para. 1 and 3 of the Law no. 51/1995, republished, as well as within the provisions of Article 26 para. 1 and 2 and Article 27 of the Law no. 36/1995 concerning public notaries and notary activity. Pursuant to the provisions of Article $9^{11}$ first thesis of the Romanian

${ }^{6}$ Legislation collection regarding the lawyer's profession. The Law no. 51/1995 for the organisation and exercise of the lawyer's profession, republished, with the subsequent amendments and completions; the Statute of the lawyer's profession; Code of ethics for EU lawyers, Universul Juridic Publishing House, Bucharest, 2005, p. 7.

7 The Romanian Union of Bars was founded through Article 7 para. 1 of the Law for the organisation and unification of the body of lawyers from 1923 (Decree no. 610/1923 published in the Official Gazette of Romania no. 251 of February 25th 1923 ), as a general body of the Bars of Romanian Lawyers, with a legal personality.

${ }^{8}$ By the Romanian Constitutional Court's Decision no. 321/2004, published in the Official Gazette of Romania no. 1144 of December 3rd, 2004, which rejected the unconstitutionality exception of Article 48 para. 1 first thesis and Article 57 para. 1 and 4 of the Law no. 51/1995, The Constitutional Court ruled that "the organisation of the lawful practice of the lawyers' profession - and as well as any activity of interest for the society - is natural and necessary, in order to determine the competence, means, and manner of practicing a profession, as well as the limits beyond which one would violate the rights of other persons or professional categories". In the same lime, must see the Decisions of the Romanian Constitutional Court no. 234/2004, published in the Official Gazette of Romania no. 532 of June 14th 2004 , and no. 233/2004, published in the Official Gazette of Romania no. 603 of July $5^{\text {th }}, 2004$.

${ }^{9}$ According to Article 59 para. 6 of the Law no. 51/1995, "the misuse of the names 'Bar', 'National Association of Romanian Bars or 'Union of Romanian Lawyers' or the names specific to the practice of lawyer's profession, as well as the use of signs specific to profession or the wearing of robes in other conditions than those stipulated by this law represent criminal offences and they are punishable by imprisonment from 6 months to 3 years or by a fine".

10 Published in the Official Gazette of Romania no. 603 of July $5^{\text {th }}, 2004$.

11 "The unions, industries and professional associations are constituted and conduct their activities according to their statutes, under the law." 
Constitution, the legislator has the freedom of regulating the conditions for constituting, organising and functioning for various types and forms of association, including the mandatory constitution of certain associations for the exercise of some professions or the fulfilling of public interest attributions. The freedom of association does not mean that any person can be part of any type of association, irrespective of their civil and professional status. In addition, the activity conducted by the Bars and by the National Association of the Romanian Bars is one of public interest, given that these associations are professional associations with specific particularities, which imposes a more comprehensive legal regulation, even in what concerns the qualities of the members, the organisation and functioning conditions, the indignities, incompatibilities, disciplinary liability and others. The examined texts of law do not force any person to be part - against his or her will - of an association, the enrolment in a Bar represents a legal condition for exercising the lawyer's profession and the membership in an association conditions the practice of the profession. Nobody is forced to practice the law or prevented from associating, but such association must abide the law. Lawyers are divided into Bars in all member-states of the European Council ${ }^{12}$.

The right of association may be exercised only by abiding the law, and not against it. It is a right specific through its nature to liberal professions. In this respect, the Constitutional Court ruled constantly as follows.

\subsection{The lawyer's capacity acquired under the law}

The Romanian Constitutional Court's Decision no. 66 of May $21^{\text {st }}, 1996^{13}$ rejects the exception of unconstitutionality of the provisions of Article 5, Article 22 and Article 78 of the Law no. 51/1995. Essentially, the Court rules that it is not possible for the jurists who are not members of the Bars of lawyers to practice law, because no reason regarding individual freedom - the one of association, implicitly - can be held for removing Article 1 para. 2 of the Law no. 51/1995, which states that the lawyer's profession may be exercised only by the member of Bars. Article 24 para. 2 of the Romanian Constitution shows that - during the trial - the parties are entitled to be assisted by a lawyer, namely by a person with the lawyer's capacity, acquired under the conditions of the law. This is an ironclad guarantee preventing legal counsel being exercised by unqualified persons and escaping the professional control of Bars of lawyers ${ }^{14}$.

${ }^{12}$ T. Toader, M. Safta, Advocacy legislation reflected in the jurisprudence of the Constitutional Court, in Justice Magazine, Dolj Bar, no. 2/2014, p. 23.

${ }^{13}$ Published in the Official Gazette of Romania no. 325 of December $5^{\text {th }}, 1996$.

${ }^{14}$ By the Romanian Constitutional Court's Decision no. 195 of April 27th, 2004, on the unconstitutionality exception of the provisions of the Law no. 51/1995, published in the Official Gazette of Romania no. 532 of June $14^{\text {th }}, 2004$, it was rejected the exception. Essentially, the regulation under organic law of the lawyer's profession is contested, because it is not included in any of the fields stated in Article 73 para. 3 of the Romanian Constitution, republished, as well as the very organisation of this profession under the law, by 
The constitutionalisation of criminal standards concerning the exercise...

By the Romanian Constitutional Court's Decision no. 88 of February $10^{\text {th }}, 2005^{15}$, regarding the exception of unconstitutionality of the provisions of Article 82 of the Law no. 51/1995 it was rejected the exception of unconstitutionality. The Constitutional Court ruled constantly in her case-law that the right of association can be exercised only under the law and not against it, reason for which not even this right, specific through its nature to liberal professions, nor the provisions of Article 40 of the Constitution are dismissed through Article $82^{16}$ of the Law no. 51/1995 for the organisation and functioning of the lawyer's profession, as it was amended through the Law no. 255/2004.

The Romanian Constitutional Court's Decision no. 688 of December $20^{\text {th }}, 2005^{17}$, rejects the exception of unconstitutionality of the provisions of Article 7 para. 3 and 4 of Government's Ordinance no. 26/2000 concerning associations and foundations and of Article 48 para. 1 first thesis and of Article 57 para. 1 and 4 of the Law no. 51/1995. The provisions of Article 48 para. 1 first thesis and Article 57 para. 1 and 4 of the Law no. 51/1995 for the organisation and exercise of the lawyer's profession were also the object of constitutionality control in cases with an identical reason and by relating to the same constitutional and conventional provisions also invoked in the current case. Hence, by the Romanian Constitutional Court's Decision no. 321 of September $14^{\text {th }}, 2004^{18}$, the

considering that the legislative document applicable in the matter is the Government's Ordinance no. 26/2000 concerning associations and foundations, with the subsequent amendments. Furthermore, by the Romanian Constitutional Court's Decision no. 44 of February $4^{\text {th }}, 2003$, published in the Official Gazette of Romania no. 161 of March 13 ${ }^{\text {th }}, 2003$, it is explained why the conditions of organisation and exercise of the lawyer's profession are stated in a special law, thus not being submitted to the general standard comprised in Government's Ordinance no. 26/2000 concerning associations and foundations, with the subsequent amendments. By the Romanian Constitutional Court's Decision no. 150 of February 10 ${ }^{\text {th }}$, 2009, on the unconstitutionality exception of the provisions under Article 1 para. 3 and under Article 82 para. 1 and 2 of the Law no. 51/1995, published in the Official Gazette of Romania no. 152 of March $11^{\text {th }}, 2009$, it is rejected the exception as groundless, the Court has ruled constantly in its jurisprudence that the lawyer's profession may be exercised only under the law, not against it.

15 Published in the Official Gazette of Romania no. 163 of February 23rd, 2005.

${ }^{16}$ By the Romanian Constitutional Court's Decision no. 200 of March 2 ${ }^{\text {nd }}, 2006$, regarding the unconstitutionality exception of the provisions of Article 3 para. 1 letters d) and e), Article 25, Article 82 para. 1 and 2 of the Law no. 51/1995, as well as of the provisions of Article 52 para. 5 of the Penal Procedure Code, published in the Official Gazette of Romania no. 299 of April 3rd 2006, it is rejected the exception. The Court also ruled on the constitutionality of the criticised texts of law, as well as on the constitutionality of the Law no. 51/1995, as a whole. By the Romanian Constitutional Court's Decision no. 260 of May 12th, 2005, published in the Official Gazette of Romania no. 548 of June 28th, 2005, the Constitutional Court rejected the unconstitutionality exception of the provisions of Article 82 of the Law no. 51/1995, ruling that it did not hinder the right of association or the principle of separation of powers. Furthermore, para. 3 of the Article 82 of the Law no. 51/1995 states that "the provisions under para. 1 and 2 do not apply to the profession of legal advisor, which will be exercised according to of the provisions of the Law no. 514/2003 on the organisation and exercise of the legal adviser's profession"; hence, no hindrance has been found, in the criticised texts of law, concerning the exercise of the legal adviser's profession. By the Romanian Constitutional Court's Decision no. 44 of February $4^{\text {th }}, 2003$ - published in the Official Gazette of Romania no. 161 of March $13^{\text {th }}, 2003$-, there is explained why the conditions of organisation and exercise of the lawyer's profession are stated in a special law, thus not being submitted to the general standard comprised in Government's Ordinance 26/2000 concerning associations and foundations, with the subsequent amendments.

${ }^{17}$ Published in the Official Gazette of Romania no. 114 of February $7^{\text {th }}, 2006$.

${ }^{18}$ Published in the Official Gazette of Romania no. 1144 of December $3^{\text {rd }}, 2004$. 
Constitutional Court rejected the exception as groundless, highlighting that such provisions - referring to the organisation of lawyers within Bars and of Bars within the National Union of Romanian Bars - did not hinder the right of association or the right to work and to choose the profession, stated by Article 40 para. 1 and by Article 41 of the Romanian Constitution, in agreement with the provisions of the international documents.

The National Union of Bars functions based on standards that do not hinder the constitutional principles, while the persons who wish to practice this profession must abide the law and accept the rules imposed by it ${ }^{19}$.

The most important social values - including the patrimonial interests of persons should be defended properly. Hence, it is necessary to incriminate and sanction the acts of unlawful exercise of a profession for which a certain training is required. The reasons for constituting various unitary organisational structures and for prohibiting the parallel constitution of other structures dedicated to the practice of the same activity, without legal support, are founded on arguments according to which the practice of law is a liberal and independent profession, and its exercise should benefit from an organised framework, pursuant to well-defined rules, the observance of which should be ensured even through means of coercive measures ${ }^{20}$.

\subsection{The incrimination of illegal exercise of the lawyer's profession}

The Law no. 51/1995, after its modification and completion by Law no. $255 / 2004$, expressly mentions in Article 1 para. 3, that "the establishment and operation of Bars outside the National Association of the Romanian Bars are prohibited", and "the acts of constituting and registering them are null and void under the law". At the same time, Article 82 para. 1 of Law no. 51/1995 was amended by Law no. 255/2004 as follows: "also, upon the entry into force of the present law, the physical or legal entities that have been authorised through other legislative documents or approved through court decisions to conduct activities of legal consulting, representation or assistance, irrespective of the fields, must end their activity under the law. The continuation of such activities is an offence and it is punishable by criminal law".

19 Romanian Constitutional Court's Decision no. 155 of March 17th 2015, regarding the unconstitutionality exception of the provisions under Article 1 para. 3, Article 50 and Article 60 of the Law no. 51/1995, published in the Official Gazette of Romania no. 259 of April 17th 2015 ; Romanian Constitutional Court's Decision no. 379 of September 24th 2013 , published in the Official Gazette of Romania no. 731 of November $27^{\text {th }}, 2013$.

20 The Romanian Constitutional Court's Decision no. 158 of March 14th 2017 , concerning the unconstitutionality exception of the provisions under Article 1 para. 2 and 3, Article 17, Article 50, Article 60 para. 2 and 6 and Article 113 para. 1 and 2 of the Law no. 51/1995, published in the Official Gazette of Romania no. 394 of May 25 th, 2017 ; The Romanian Constitutional Court's Decision no. 129 of March 13 ${ }^{\text {th }}, 2014$, published in the Official Gazette of Romania no. 291 of April 22 ${ }^{\text {nd }}, 2014$; The Romanian Constitutional Court's Decision no. 509 of June 30th 2015 , published in the Official Gazette of Romania no. 580 of August $3^{\text {rd }}$, 2015; The Romanian Constitutional Court's Decision no. 412 of October $8^{\text {th }}, 2013$, published in the Official Gazette of Romania no. 712 of November $20^{\text {th }}, 2013$. 


\section{The constitutionalisation of criminal standards concerning the exercise...}

In addition, according to Article 82 para. 2, after its modification by Law no. 255/2004, "upon the entry into force of the present law, the effects of any legislative, administrative or jurisdictional document having recognised or approved activities of legal consulting, representation or assistance contrary to the provisions of the law hereof cease under the law" (Article 82 para. $2^{21}$ became Article 107 after the republication of the Law no. 51/1995).

In what concerns the condition of having a Bar membership and of being featured on the table of lawyers, we must mention that the legislator took into account the actual and current right of a person to practice law because it is possible, on one hand, for a person to be included legally in the practice of law, but without being featured on the table of lawyers yet, case in which the commission of such offence is not taken into account. On the other hand, according to Article 26 of the Law no. 51/1995, it is possible for the lawyer's capacity of a person to cease, without said person to be removed immediately from the table of lawyers or, according to Article 27 of the Law no. $51 / 1995$, the lawyer's capacity of a person may be only suspended (i.e. the person is not entitled to exercise the lawyer's profession, though being featured on the table of lawyers, case in which it is considered an offence to carry out activities specific to the lawyer's profession).

As for the non-retroactive application of the law - except for the more favourable criminal or contravention law - it results in terminis in the content of Article 82 para. 1

${ }^{21}$ By the Romanian Constitutional Court's Decision no. 61 of February 2 ${ }^{\text {nd }}, 2006$ - regarding the unconstitutionality exception of the provisions of Article 82 para. 1 and 2 of the Law no. 51/1995, published in the Official Gazette of Romania no. 176 of February 23 $3^{\text {rd }}, 2006$ - it is rejected the exception, based on the reasons showed in the Romanian Constitutional Court's Decision no. 260 of May 12 $2^{\text {th }}, 2005$, published in the Official Gazette of Romania no. 548 of June 28 ${ }^{\text {th }}, 2005$, in the Romanian Constitutional Court's Decision no. 88 of February $10^{\text {th }}, 2005$, published in the Official Gazette of Romania no. 163 of February 23 2005 and in the Romanian Constitutional Court's Decision no. 1070 of September $16^{\text {th }}, 2010$ - concerning the unconstitutionality exception of the provisions of Article 281 of the Penal Code and Article 1 para. 3 and Article 82 para. 1 and 2 of the Law no. 51/1995, published in the Official Gazette of Romania no. 732 of November $3^{\text {rd }}, 2010$ - it is rejected:

- as inadmissible the exception regarding Article 281 of the Penal Code because the author of the exception fails to formulate valuable unconstitutionality criticism, but he is really dissatisfied of the way the criminal prosecution bodies and the court apply the legal provisions in question, distinguishing between the general and the special criminal laws. Nonetheless, this aspect does not fall under the unconstitutionality control exercised by the Court, the competence pertaining to the court invested with the ruling of the litigation, namely of to the higher courts, within the appeal methods under the law.

- and as unfounded the exception regarding Article 1 para. 3 and Article 82 para. 1 and 2 of the Law no. 51/1995 because the Court also rejected a similar exception, namely Decision no. 736 of May $12^{\text {th }}, 2009$, published in the Official Gazette of Romania no. 461 of July $3^{\text {rd }}$, 2009, without new elements to determine the reconsideration of the Court's case-law. Through the Romanian Constitutional Court's Decision no. 1354 of October 22nd 2009, concerning the unconstitutionality exception of the provisions under Article 1 para. 3, Article 9 para. 2, Article 25 and Article 82 para. 1 and 2 of the Law no. 51/1995, published in the Official Gazette of Romania no. 844 of December 7 th, 2009 , the exception was rejected as unfounded. The same solution was adopted through the Romanian Constitutional Court's Decision no. 150/2009, published in the Official Gazette of Romania no. 152 of March 11 2009. 
and 2 of the Law no. 51/1995, amended by the Law no. 255/2004. Law no. 51/1995 itself states that from the date of the entry into force, ex nunc, the Bars constituted or registered previously cease their activity under the law and that the continuation of specific activities represents an offence. The new Law does not apply retroactively in relation to the juridical situations entirely constituted or terminated, as well as in relation to the juridical effects entirely consumed until the emergence of the new law. However, the new law is applicable immediately in what concerns the effects of certain past juridical situations, if these effects continue after the entry into force of the new law.

As for the possibility of supressing the juridical effects of a Court's judgment ruled before the entry into force of the new law, it is worth noting that the provisions of the Law no. 51/1995 - introduced through the Law no. 255/2004 - were not adopted concerning a certain "constitutional Bar", founded outside the National Association of the Romanian Bars, but regarding any "Bars" in general, which would be founded against the law or by eluding the legal provisions. According to some opinions, there is no impossibility principle according to which the legislator would have the authority of regulating social relations in a certain way, including those derived from jurisdiction acts, that it is not impossible to reconsider certain "juridical effects" existing in the rule of law, through general and impersonal rules.

The ECtHR, second section, through the Decision of October $12^{\text {th }}, 2004$ on the admissibility of the request no. 2405/03 presented by the representative of the "Bonis Potra" Association (one of the associations to have founded "constitutional Bar") decided unanimously that the request in question was "inadmissible". I cite the following from the grounds for the ruling: "the Court noted that (...) in particular, the members of the association had carried out specific actions, namely the setting up of a Bar association and had usurped prerogatives that belonged exclusively to the Union of Romanian Lawyers (...). At that moment, taking into account the margin of appreciation granted to the states in this matter, the Court believes that the dissolution of the 'Bonis Potra' Association is proportional with the purpose in question and that the reasons invoked by domestic jurisdictions have proven relevant and sufficient. The Court reminds that - according to its constant case-law - the liberal professions are establishments of public law, regulated by law, with purposes of general interest. Hence, they are not under the incidence of the Article 11 of the ECHR".

The Romanian Highest Court of Cassation and Justice has ruled that "the legal assistance granted during trial to a defendant or an accused by a person who had not acquired the lawyer's capacity under the Law no. 51/1995 equated to the lack of legal defence" 22 . Furthermore, the grounds for the ruling include as follows: "in relation to

22 The Romanian Highest Court of Cassation and Justice, united sections, dec. no. XXVII of April 16 ${ }^{\text {th }}, 2007$, published in the Official Gazette of Romania no. 772 of November $14^{\text {th }}, 2007$. Currently, the main interest is the capacity of the suspect or the accused, according to the Penal Procedure Code. Furthermore, if the legal assistance of the accused was mandatory and if he/she was assisted throughout the trial by a person who did not acquire the lawyer's capacity in the conditions of the Law no. 51/1995, it is equating with the accused's

\section{CONSTITUTIONAL LAW REVIEW}


the provisions of Article 2 pnt. 3 and Article 4 of the Law no. 303/2004 regarding the statute of the judges and the prosecutors, republished, 'the judges and the prosecutors are forced to ensure - through their entire activity - the supremacy of the law'. Hence, the judicial bodies have to not only to take the measures necessary to ensure the defence of a defendant or an accused throughout a trial, when it is mandatory, under the law, but also make sure that legal assistance should be provided by a person who had acquired the lawyer's capacity under the Law no. 51/1995, as it was amended and completed through the Law no. 255/2004 because otherwise the legal assistance in question would be considered lack of defence". By the Romanian Constitutional Court's Decision no. 1177 of November $6^{\text {th }}, 2008^{23}$, regarding the exception of unconstitutionality of the provisions of Article 56 letter c), Article 58 and Article 227 para. 1 letter c) of the Law no. 31/1990 regarding companies, as well as under Article 82 para. 1 and 2 of the Law no. 51/1995, the exception is rejected. The same solution was adopted through the Romanian Constitutional Court's Decision no. 392 of March $25^{\text {th }}, 2008^{24}$.

By the Romanian Constitutional Court's Decision no. 364 of March $17^{\text {th }}, 2009^{25}$, regarding the exception of unconstitutionality of the provisions within the Law no. 51/1995 about the organisation and exercise of the lawyer's profession, the Court rejects the exception as inadmissible. The Court rules that the issue of the legal personality of lawyer Bars is not related to constitutionality, but to regulation or to the interpretation and application of the law. However, according to Article 2 para. 3 of the Law no. 47/1992 on the organisation and functioning of the Constitutional Court, it "rules only on the constitutionality of the acts for which it was notified, without being able to amend or complete the provisions submitted to control". The Court also rejects the criticism according to which the provisions of the Law no. 51/1995 do not allow the functioning of lawyers' Bars other than those carrying out their activity based on this normative act, because it involves the modification of the legal provisions concerning the exception of unconstitutionality in the sense desired by the author. The author's exception support, according to which, "despite the obligation stated under Article 48 para. 2 of the Law no. 51/1995, National Association of the Romanian Bars functions without legal personality and the members of 'Bota' Bars, who are not part of the so-called traditional Bars, are discriminated against simply because they do not pertain to a Bar with legal personality" has nothing to do with the ruling of the substance of the litigation at the common law court. Consequently, pursuant to Article 29 para. 6 of the Law no. 47/1992 on the organisation and functioning of the Constitutional Court, the exception of unconstitutionality cannot be invoked.

lack of defence and is included in the appeal for annulment stated by Article 426 letter f) of Penal Procedure Code - penal decision no. 139/A of April 17th, 2015 of the Romanian Highest Court of Cassation and Justice, available at www.scj.ro.

${ }^{23}$ Published in the Official Gazette of Romania no. 866 of December 22nd, 2008.

${ }^{24}$ Published in the Official Gazette of Romania no. 309 of April 21 $1^{\text {st }}, 2008$.

${ }^{25}$ Published in the Official Gazette of Romania no. 237 of April 9't 2009. 
At the level of case-law ${ }^{26}$, the practice of the courts of law was not unitary in the appreciation of the lawyer's capacity of the members of "parallel Bars". Hence, were noted the following trends, namely of accepting and allowing the members of the "Constitutional Bar" to provide legal assistance and representation to ask the members of the "Constitutional Bar" to give "evidence regarding the lawyer's capacity pursuant to the Law no. 51/1995" and in the absence of that, the person would not be allowed to provide legal assistance and representation or to establish that the trust mandate was given to a person who is not a lawyer and - in conformity with the provisions of Article 83 para. 1 of the Civil Procedure Code - it is not allowed to draw conclusions.

On April $25^{\text {th }}, 2012$, the Deva District Court ${ }^{27}$ decided the sentencing to 6 months in jail of Pompiliu Bota, "the dean of the Constitutional Bar", for having exercised unlawfully the lawyer's profession and to 6 months of imprisonment for the offence of complicity to unlawful exercise of a profession. Upon merging the two sentences, the most severe one was preserved, namely 6 months of imprisonment. In addition, the court ordered the suspended execution of the sentence ruled in the case of Pompiliu

\footnotetext{
${ }^{26}$ An example from the judiciary practice is the decision no. 597 of May 27 $7^{\text {th }}, 2014$, of the Cluj-Napoca County Court, regarding the unlawful exercise of a profession, according to Article 281 of the Penal Code, committed by the defendant B.I. He pretended to be a lawyer, legitimised as a lawyer and his card bore a stamp that seemed to have been issued by the Cluj Bar. The defendant came before the court in 2008 as the plaintiff's lawyer. After a lawyer in the room pointed out that the defendant was not part of the Bar and after several check-ups, the Cluj Bar was contacted, which noted that "the fact that the so-called B.I. has never been a member in this professional association". The defendant B.I. stated his innocence concerning the offence of unlawful exercise a of the lawyer's profession. The defendant has argued that he "would have acquired legally (by passing an exam) the lawyer's capacity definitively on 30.07.2004 and he is part of the National Union of Romanian Bars the Cluj Bar - the B. branch (...), the only Bar registered and legally in the present in Romania, given that the other Bars (the traditional ones) were dissolved through the Law no. 3/1948". The presentation within the notification of the criminal ruling proves that the so-called Bars founded by B.P. were actually dissolved, the legal entity's request for registration was rejected through an irrevocable ruling. At the same time, they feature the succession of the legislative documents to indicate that neither the Bars or the law practice colleges were not dissolved in Romania, nor was the law practice activity, thus having a continuous character. It has been decided that the defendant's defence was groundless, "the defendant's defence according to which the successive amendments of the Law no. 51/1995 produced no effects on the court's ruling 79/PJ/2003 that authorized the functioning of an association with the purpose of founding Bars is also groundless". At the same time, the stated lack of intention is not consistent with the defendant's actions, who used a fake card, seemingly issued by the Cluj Bar, the purpose hereof being the unlawful exercise of the lawyer's profession for material gain. The defendant was found guilty by the court, while the punishment consisted of a fine, namely 4.800 RON (accounting to 240 fines for 240 days, each one worth $20 \mathrm{RON}$ ), to which the legal fee of 200 RON was added. At the same time, it was brought to the defendant's attention that it was possible "to replace the number of fine-days not executed in ill-faith with a corresponding number of days of imprisonment". Another example from the case-law is the penal decision no. 455 of September $5^{\text {th }}, 2016$, the Sibiu County Court, where the defendant in his capacity as a member of the Constitutional Bar - for the same criminal resolution - exercised acts specific to the lawyer's profession, thus committing several separate acts punishable under the criminal law, namely deceit and unlawful exercise of the profession, thus being sentenced to one year of imprisonment and three months of imprisonment, respectively. Also see the penal ruling no. 1417 of September 17th, 2015, of the Galati District Court and the penal decision no. 124 of November $13^{\text {th }}, 2015$, of the Iasi Court of Appeal.

${ }^{27}$ By the decision no. 722 of May 29th 2012 , the Alba Iulia Court of Appeal maintains the ruling no. 538 of April 5 $5^{\text {th }}, 2012$, of the Deva District Court, http://www.barou-alba.ro/upload/29_89_Decizie_penala_nr_722_ din_29_mai_2012.pdf.
} 
The constitutionalisation of criminal standards concerning the exercise...

Bota for a probation period of 2 years and 6 months. The ruling by the Deva District Court was appealed by Pompiliu Bota on April 26 $6^{\text {th }}, 2012$, at the Alba lulia Court of Appeal, but his appeal was rejected on May 29th 2012 . The sentence ruled against Pompiliu Bota by the Deva District Court remained definitive as well. In addition, his appeal for annulment was rejected ${ }^{28}$.

Through the Romanian Constitutional Court's Decision no. 339 of April $10^{\text {th }}, 2012^{29}$, the Constitutional Court has acknowledged that the society cannot allow for certain professions, such as physician, pharmacist or dentist, to be practiced by untrained persons, lacking responsibility in case of dangerous or harmful consequences. The fact that the lawyer's profession requires a certain type of training and that it is subjected to authorisation expresses the need to defend social values of outmost importance, including the life and physical and mental integrity of persons, as well as their patrimonial interests. This is the option of the legislator, determined by a certain opportunity, which is legislated by the Parliament.

Through the Highest Court of Cassation and Justice's Decision - RIL no. 15 of September $21^{\text {st }}, 2015^{30}$, it has been determined that in the interpretation and application of the provisions under Article 348 of the penal Code, the exercise without the right to a profession or activity stated under Article 348 of the penal Code is the exercise without law of activities specific to the lawyer's profession within entities that are not part of the professional organisation forms acknowledged by the Law no. 51/1995 regarding the organisation and exercise of the lawyer's profession, republished, with the subsequent amendments and completions.

The purpose of the Law no. 51/1995 is to ensure qualified legal assistance. It is imperiously necessary for the persons who wish to practice this profession to abide by the law and to accept the rules imposed as a consequence. Society cannot allow for certain professions to be practiced by untrained persons, lacking responsibility in case of harmful patrimonial consequences. The fact that the same conditions, bearing the same legal consequences, were also imposed to the lawyer's profession is an option of the legislator, determined by a certain opportunity, which is legislated by the Parliament's activity. The legal provisions of the Law no. 51/1995 issued by the legislator are meant to protect the social relations concerning the exercise of a liberal profession, namely of the lawyer's profession, so that it may be exercised only by abiding the law, and not against it. Whereas the practice of law is a liberal and independent profession, its exercise should take place in an organised framework, in conformity with

${ }^{28}$ http://ro.wikipedia.org/wiki/Baroul_Constituţional\#cite_note-a2012-05-30-2.

${ }^{29}$ Published in the Official Gazette of Romania no. 374 of June 1 ${ }^{\text {st }}, 2012$.

${ }^{30}$ Must see the Romanian Highest Court of Cassation and Justice, united sections, decision no. 15 of September 21st, 2015, published in the Official Gazette of Romania no. 816 of November $3^{\text {rd }}, 2015$. By the Law no. 25/2017 it was amended Article 26 of the Law no. 51/1995, being expressly mentioned in the Article 26 para. 3 of the Law no. 51/1995 that "the act of a person who carries out activities specific to the legal profession within entities that are not part of the forms of professional organization recognized by this law constitutes an offense and is punishable under criminal law". 
predetermined rules, the observance of which should be ensured even through means of coercive measures, such reasons entailing the constitution of unitary organisational structures and the prohibition of the parallel constitution of other structures dedicated to the practice of the same activity, without legal support ${ }^{31}$.

The exercise of the lawyer's profession ${ }^{32}$ is regulated through the Law no. 51/1995, which was amended in the Parliament in 2011 and 2016. Right from the first article of this law we comprise a first condition for the exercise of the lawyer's profession, namely the lawyers have to be included in the table of the Bar to which they belong, while the Bar should be a component of The National Union of Romanian Bars ${ }^{33}$.

The Penal Code specifies the punishment for the offence of unlawful exercise of the profession, but the regulation within article 348 of the Penal Code is as the "blank standard". More precisely, the text of the law does not indicate the professions and activities for which unlawful exercise intervenes the prison sentence (from 3 months to one year) or a fine. The regulation of specific professions and activities punished pursuant to Article 348 of the Penal Code is done through extra-criminal laws. The commission of the offence takes place when at least one act of exercise of the lawyer's profession - mentioned in Article 3 of the Law no. 51/1995 - occurs and the consequence is produced, namely the state of danger. Hence, unlike the framework offence, which is a habitual offence, for the existence of this consumed offence it is necessary and sufficient to conduct one activity specific to the lawyer's profession.

The lawyer's profession and activities are included in those professions or activities whose unlawful exercise is punished under the criminal law, within Article 348 of the Penal Code. Article 25 of the Law no. 51/1995 specifies the criminal nature of the offence called unlawful exercise of the activities specific to the lawyer's profession. Furthermore, Article 25 para. 3 mentions that "the act of a person exercising activities specific to the profession of lawyer within entities that are not part of the forms of professional organisation as recognised by the present law constitutes an offence and is punished according to the criminal law". The unlawful exercise of the lawyer's profession may involve the use or creation of documents, but they are null and void, according to Article 25 para. 4 of the Law no 51/1995, as it says that "the acts specific to the profession of lawyer, accomplished publicly by a person who has not acquired the capacity of a lawyer under the present law, are null and void".

31 The Romanian Constitutional Court's Decision no. 158 of March 14th 2017 , published in the Official Gazette of Romania no. 394 of May 25th 2017 . In the same respect, must see the Romanian Constitutional Court's Decision no. 509 of June 30 th 2015 , published in the Official Gazette of Romania no. 580 of August $3^{\text {rd }}$, 2015 and the Romanian Constitutional Court's Decision no. 349 of May 11 $1^{\text {th }}, 2017$, published in the Official Gazette of Romania no. 660 of August 10th 2017 ;

${ }^{32}$ Must see the Bucharest Court of Appeal, penal section, penal decision no. 119/A/2017, available at http://portal.just.ro; the Romanian Highest Court of Cassation and Justice, penal section, penal decision no. 935/2016; the Romanian Highest Court of Cassation and Justice, penal section, penal decision no. 449/A/2015; the Romanian Highest Court of Cassation and Justice, penal section, penal decision no. 70/A/2015.

33 Ibidem. 
The constitutionalisation of criminal standards concerning the exercise...

Only the state has the right and obligation to organise, under the law, the institutional framework of law practice and to ensure the effective and corresponding exercise of the right to defence in a fair trial, including through or with support from a lawyer. Consequently, the organisation of law practice and the exercise of the lawyer's profession outside the framework institutionalised by law or in other conditions than those provided by the law are categorically inadmissible.

2. The regulation of acquiring the lawyer's capacity or of exercising the profession must respect the incident situations of indignity

In what concerns the provisions of Article 14 letter b) ${ }^{34}$ the final thesis of the Law no. 51/1995, the Court considered the formulated exception as unfounded and has ruled that the persons exercising this honourable profession should have an impeccable moral profile. It is unconceivable for persons with (serious) criminal convictions to participate to the act of justice. This provides a guarantee to litigants, as the regulation in the matter of lawyer's indignity is normal. The legislator understood to punish with the maximum sentence - exclusion from the profession - only the wilful commission of the offence, thus excluding involuntary offences; the motivation was that, given that the lawyers had no ill intention, it may not be assumed that their probity and correctness were affected.

Pursuant to the legislation of lawyers, the indignity cases are expressly and limitedly stated by law and they are assessed upon joining the profession, upon submitting an application to be included in the table of lawyers with the right to exercise the profession, as well as all throughout the exercise of said profession. The cease of the lawyer's capacity may be taken by the Bar's council and it entails the removal of the person in question from the table of lawyers.

Through the Romanian Constitutional Court's Decision no. 225 of April $4^{\text {th }}, 2017$, regarding the exception of unconstitutionality of the provisions of Article 14 letter a) ${ }^{35}$ and Article 27 letter d) of the Law no. 51/1995 for the organisation and exercise of the lawyer's profession, the Court admits the exception of unconstitutionality and concludes that the phrase "such as to prejudice the prestige of the profession" of Article 14 letter a) of the Law no. 51/1995 is unconstitutional. Hence, three conditions must be

34 The Romanian Constitutional Court's Decision no. 629 of October 27th 2016 , published in the Official Gazette of Romania no. 36 of January 12 ${ }^{\text {th }}, 2017$, concerning the unconstitutionality exception of the provisions of Article 48 and of Article 89 para. 1 letter e) related to Article 14 letter b) the final thesis of the Law no. 51/1995, according to the latter, the following are unworthy of being a lawyer the person who committed abuses which violated the human rights and fundamental freedoms, established by court decision, or has committed serious disciplinary offences punishable by the exclusion from the profession as a disciplinary sanction.

35 The following categories are not worthy of being a lawyer: a) the person finally convicted by a court order 'to imprisonment for committing a wilful offence, such as to prejudice the prestige of the profession'. 
met concurrently in order to even discuss indignity within the Romanian Constitutional Court, namely: a) a person must be sentenced to a definitive punish by a court to imprisonment (the law does not specify whether the sentence must be executed or suspended); b) the act must have been done with a wilful offence; c) the act must produce a prejudice to the profession.

The Court has ruled that the phrasing lacks precision and clarity, taking into account that it fails to state clearly which wilful offences prejudice the lawyer's profession. Thus, a premise is created for the different and discriminatory application of the law ${ }^{36}$, because of arbitrary interpretations or appreciations. The express lack of considering circumstances of the offences whose nature brings prejudice to the prestige of the lawyer's profession allows arbitrariness and makes it possible to apply the sanction of exclusion from the profession differently, depending on the subjective evaluation of the lawyer's profession structures with competence over the indignity cases. Hence, a Bar may exclude a lawyer for having committed a wilful offence, while another Bar may decide to maintain a lawyer as a member, despite the same act.

Therefore, the legislator has to create an edifying normative content and to establish a coherent and clear legislative framework in what concerns the concrete conditions for the cease of the lawyer's capacity, by excluding the person from the

${ }^{36}$ Must see the Suceava Court of Appeal, penal section, penal decision no. 89 of November 25 $5^{\text {th }}, 2016$, where the Suceava Court of Appeal admitted the agreement of recognising of the defendant-lawyer, thus sentencing him to one year and four months of imprisonment for the offence of influence peddling, stated by Article 291 para. 1 related to Article 308 of the Penal Code and to Article 6 of the Law no. 78/2000 with the application of Article 5 of the Penal Code and Article 91 of the Penal Code (the suspension of executing the punishment under supervision). The defendant-lawyer directly and intently claimed from a Polish citizen the amount of 5,000 EUR, stating that he would be giving it to the trustee in bankruptcy nominated for the case. He suggested that he had influence and that he could persuade him to accomplish his professional tasks in a favourable way for the Polish citizen. Through the decision, the defendant was obligated to observe several monitoring measures and to attend a social reintegration programme conducted by the Probation Service of Suceava. However, no mention is made concerning the exercise of the lawyer's profession by the lawyer with a criminal conviction. On November $15^{\text {th }}, 2019$ (when this footnote was written), the lawyer was still a member of the Suceava Bar, he was not excluded from the profession. The Council of the Suceava Bar has assessed that in this situation, the institution of indignity is not incident. By the decision no. 762 of August 18 $8^{\text {th }}, 2016$, the Court of Caraş Severin states that through decision no. 11/19.01.2016, the Argeş Bar removed the capacity of lawyer held by the plaintiff, by considering him unworthy of exercising the profession, taking into account that he had been convicted by ruling no. 339/08.10.2014 by the Bucharest Court of Appeal, as well as by decision no. 190/27.05.2015 to four years of imprisonment for the offence of tax evasion in his capacity of associate manager and tax representative of an association of lawyers. By the penal decision no. 3848 of June 30 ${ }^{\text {th }}, 2016$, the Bucharest Court of Appeal maintains the criminal ruling no. 7330/28.10.2015 of the Bucharest Court and rules that there is a definitive conviction to imprisonment for a wilful offence and that this conviction makes the author unworthy of exercising the lawyer's profession. It is irrelevant that the offences of influence peddling were not committed while exercising the profession and that the criminal court did not prohibit the exercise of the profession, given that the legislator did not mention such conditions in the procedure of excluding a lawyer from a Bar, the measure of ceasing the lawyer's capacity is necessary if there is a definitive criminal conviction involving imprisonment, for a wilful offence. By the decision no. 1165 of April 6 ${ }^{\text {th }}$, 2016, the Bucharest Court of Appeal rules that such a criminal behaviour of the plaintiff has imposed the measure of ceasing her lawyer's capacity and removing her from the table of lawyers, she had the possibility of carrying out activities in other fields, which would allow her to exercise a profession even in the event of a criminal conviction, as a jurist or as something else in the same field; www.rolii.ro (15.09.2019).

CONSTITUTIONAL LAW REVIEW 


\section{The constitutionalisation of criminal standards concerning the exercise...}

profession due to the indignity case. Hence, until the Parliament circumstantiates expressly the sphere of wilful offences leading to a lawyer's indignity, the applicable legal text of Article 14 letter a) of the Law no. 51/1995 does not give to the lawyer's profession bodies the right to assess from case to case the types of offences for which a lawyer may be considered unworthy for the position. Consequently, a lawyer who falls within the limits of this legal text will be considered unworthy, regardless of the offence for which he/she was convicted, thus leading to a loss of the lawyer's capacity, pursuant to Article 27 letter d) of the Law no. 51/1995.

The Court rules that the disciplinary sanction of exclusion from the profession reflects the principle of dignity and honour of the lawyer's profession and it represents a guarantee of the morality and professional probity for the members of a Bar. They must refrain from committing antisocial acts that may put them in a negative light.

Pursuant to the Romanian Constitutional Court's Decision no. 847 of July $8^{\text {th }}$, $2008^{37}$, the Court has determined that through its effect the unconstitutional provision ceases its application in the future. In addition, The Constitutional Court has appraised that the decision of concluding the unconstitutionality may not be a mere abstract law tool applied only to the legal relations to arise in future hypothetical situations, because it would essentially lose its concrete character. Henceforth, according to the Romanian Constitutional Court's Decision no. 126 of March $3^{\text {rd }}, 2016^{38}$, the Court decided that "the future application of its decisions concerns both the legal situations to arise - facta futura and pending legal situations - and exceptionally those situations that became facta praeterita". The councils of the Bars and the National Association of the Romanian Bars's Council should consider the legal provision in force, after the publication of the Romanian Constitutional Court's Decision no. 225/2017 in the Official Gazette, in all unexamined situations, for any reason, lack of knowledge or indifference, and that should be examined, but also in re-examination situations and in case of convictions occurred after the publication of the Decision made by the Constitutional Court in the Official Gazette, for acts committed before publishing the Decision and in case of definitive convictions for acts committed after publishing the Decision of the Constitutional Court in the Official Gazette of Romania. Starting with June $22^{\text {nd }}, 2017$, in all cases regarding indignity on the dockets of the Bars' councils and the National Association of the Romanian Bars's Council, regardless of the date of the definitive conviction to imprisonment for a wilful offence, the legal text of Article 14 letter a) of the Law no. 51/1995 would be applied, by removing the phrase deemed unconstitutional $^{39}$. This means, in my opinion, that the Bars' councils only have the obligation of assessing - pursuant to Article 26 para. 3 of the Statute of the lawyer's

37 Published in the Official Gazette of Romania no. 605 of August $14^{\text {th }}, 2008$.

38 Published in the Official Gazette of Romania no. 185 of March 11 2016.

${ }^{39}$ S. Deaconu, Specialized opinion on the application of the Romanian Constitutional Court's Decision no. 225 of April 4th, 2017 , available at http://www.unbr.ro/wp-content/uploads/2017/09/Opinie_stiintifica_UNBR_ 2017_nedemnitatea_150917.pdf.

CONSTITUTIONAL JURISDICTIONS 
profession - whether the criminal conviction of the lawyer in question is a definitive one for a wilful offence, of assessing his/her indignity and to order the cessation of the lawyer's quality. It is dangerous to entrust a local professional body with appraising the consequences of a criminal conviction. Such an approach has different and undesirable solutions, given the potential degree of subjectivity.

The provisions of Article 147 para. 4 of the Romanian Constitution state that "as from their publication, decisions shall be generally binding and effective only for the future". The effects of the decisions taken by the Constitutional Court are erga omnes as from their publication in the Official Gazette of Romania. This is a procedure standard determining the demarche carried out to establish whether a person is no longer worthy of being a lawyer, while procedure standards are of immediate applicability.

The opinion also shared by the National Institute for the Training and Improvement of Lawyers ${ }^{40}$ is that after the publication of the Romanian Constitutional Court's Decision no. 225/2017, both the Bars' councils and the council of the National Association of the Romanian Bars are entitled to assess only whether the cumulative conditions stated by Article 14 letter a) of the Law no. 51/1995 are met, without the competence of determining whether a criminal conviction would bring or not a prejudice to the prestige of the lawyer's profession.

For instance, hypothetically, a lawyer committed a wilful criminal act before the publication of Romanian Constitutional Court's Decision no. 225/2017, which was not considered to affect the prestige of the profession pursuant to the practice of the professional bodies or pursuant to the case-law in the matter at that point. After the publication of the decision, such a lawyer may be considered unworthy when appraising his or her worthiness or lack thereof, case in which his lawyer's capacity will cease. The person in question would be in the situation of losing her right to exercise the profession. In this instance, through the decision of the Bar's Council - before the entry into force of the Romanian Constitutional Court's Decision no. 225/2017 - from the lawyer was not taken away the right to exercise his profession. It was determined that the criminal conviction did not bring any prejudice to the lawyer's profession. However, by the National Association of the Romanian Bars's Council's decision - after the emergence of the Court's decision - it was ruled that the person was unworthy, which entailed an exclusion from the profession. During the analysis, they took into account the immediate effects of the Court's decision, which excluded the possibility of professional bodies' appraisal regarding the effects of the conviction. Consequently, the court could either admit the lawyer's complaint, thus annulling the decision of the Bar's Council - pursuant to the principle of non-retroactive character of the criminal law and of tempus regit actum - and preserving the lawyer's professional dignity, by taking into

${ }^{40} \mathrm{~T}$. Briciu, address to the National Union of the Romanian Bars, available at http://www.unbr.ro/seda-publicitatii-opinia-i-n-p-p-a-intocmita-la-solicitarea-presedintelui-u- $n$ - $b$-r-cu-privire-la-modul-de-interpretare -si-aplicare-a-dispozitiilor-legale-vizate-de-Decision-curtii constitutionale-a/.

CONSTITUTIONAL LAW REVIEW 
The constitutionalisation of criminal standards concerning the exercise...

account the law in force when the appealed decision was taken, or the complaint would be rejected, with the consequence of maintaining the decision of National Association of the Romanian Bars's Council, based on the Romanian Constitutional Court's Decision no. 225/2017 of the Constitutional Court.

Both the case-law and the doctrine admitted unanimously that an Administrative Court may exercise only a legality control of the administrative act, not an opportunity control. Namely, it may not replace the issuing body, but it can and must appraise whether the decision of the Bar's Council and the decision of the National Association of the Romanian Bars's Council were made under the law in force at the moment of their issuance. The court may not itself declare a lawyer's indignity or order the cease of the lawyer's capacity, it may only create an obligation in the task of professional bodies.

The Statute of the lawyer's profession mentions under Article. 26 para. 1 that, in order to apply the provisions of the Law no. 51/1995, the indignity cases must be appraised both upon joining the profession and upon re-registering on the table of lawyers with the right of exercising the profession, as well as throughout the entire exercise $^{41}$, which also means during the time of the cease (except for death) or suspension of the lawyer's capacity. The doctrine states that: "in the case of the moral condemnation and disapproval of a convicted criminal, they no longer enjoy the required

${ }^{41}$ Through Decision no. 1218 of May 30 30 th 2011 , the Bucharest Court of Appeal considers that the National Association of the Romanian Bars's Council justly annulled the decision of the Bucharest Bar Council, which had ruled on preserving the plaintiff's the lawyer's profession exercise, given that the plaintiff violated the dignity clause in both cases, because the criminal decision of conviction for influence peddling entailed a prohibition of exercising the lawyer's profession. The illegal character of the decision taken by the Bucharest Bar Council is obvious, because it ignores the provisions of Article 4 letters a) and c) of the Law no. 51/1995. There is no objective justification for the Council having adopted two different decisions in similar situations, given that the female defendants C.I.A. and S.M.L. were convicted based on the aforementioned criminal decision. Through the decision no. 3491 of June 13 ${ }^{\text {th }}, 2016$, the Bucharest Court of Appeal states that the indignity case was applied justly, by corroborating the provisions of Article 27 letter d) with Article 14 letter a) of the Law no. 51/1995. The legislator does not mention the mandatory character of hearing the lawyer when analysing an incompatibility case, although in this case the recurrent was invoked. In addition, the Bar's Council is not compelled to wait for the motivation of the definitive decision taken by the Romanian Highest Court of Cassation and Justice before issuing the decision of ceasing the lawyer's capacity, the date of the definitive criminal sentence is the date when the appeal decision was ruled, not the drafting date (Article 551 pnt. 4 of the Penal Procedure Code), even more as the solution of the judiciary control Court is not to change the first Court's solution, but to reject the appeals, because its goal is to consolidate from a legal grounds perspective the solution of the first Court. Concerning the definitive criminal conviction as res judicata, neither the Administrative Court nor the litigation parties are entitled to discuss its legality and grounds. Through the decision no. 983 of February 11 1 th 2014 , the Bucharest Court rules that the decision of the Bucharest Bar no. $1057 / 23.05 .2012$ of exclusion from the profession was correctly and legally issued, being motivated through the criminal ruling no. 30/F/11.02.2011 of the Bucharest Appeal Court through which the plaintiff - a lawyer from the Bucharest Bar - was sentenced to one year and four months in jail (suspended sentence) for having committed the offence of influence peddling. The conviction for the offence of influence peddling unequivocally brings prejudice to the dignity of the lawyer's profession. Through the decision no. 64 of March $7^{\text {th }}, 2014$, the Timisoara Appeal Court rules as legal and justified the decision of the Timişoara Bar regarding the exclusion from the Bar of the female lawyer convicted definitively for a corruption offence, one committed in participation with her husband, in his turn former vice-president of the Appeal Court in Timisoara, acts which entail indubitably the indignity of exercising the lawyer's profession - www.rolii.ro $(29.10 .2018)$.

CONSTITUTIONAL JURISDICTIONS 
reputation or confidence, not even after executing the punishment, because the status is of a former convicted felon. Hence, he is forbidden from exercising certain positions, dignities or activities, (...) such extra-criminal consequences of the convictions (...) are stipulated specially through laws regulating particular activities or functions, which require mainly the moral integrity of the persons fulfilling them, such as the position of magistrate, lawyer and others. The status of former convicted felon is considered incompatible with certain state positions with a particular resonance in the social conscience" $^{\prime 42}$.

De lege ferenda, I believe that the texts of Article 14 letter a), as well as Article 12 para. 1 of the Law no. 51/1995 should be modified similarly to the regulation of the magistrates' statute [Article 14 para. 2 letter c) corroborated with Article 33 para. 1 of the Law no. 303/2004], public notaries [Article 22 letter d) of the Law no. 36/1995] or judicial trustees [Article 15 letter d) of the Law no. 188/2000], texts that enforce the absence of criminal history. Consequently, a person who lost the lawyer's capacity following a decretory conviction to imprisonment for a wilful offence should not be allowed to join the practice of law again, even if they may have been rehabilitated pursuant to the Penal Code, this is a totally different aspect from the indignity case provided in Article 14 letter c) of the Law no. 51/1995, where the indignity state "is limited in time", as per the duration established through a court or a disciplinary ruling leading to an interdiction of exercising the profession. The indignity state stopes after the expiration of this period.

In what concerns the procedure of ruling on the existence of indignity states, Article $26^{3}$ of the Statute shows that - after examining the court or disciplinary rulings pronounced pursuant to Article 14 of the Law no. 51/1995 - the Bar's Council ${ }^{43}$ decides

${ }^{42}$ C. Bulai, Criminal law manual. The general part, All Publishing House, Bucharest, 1997, pp. 621-622.

43 By decision no. 250 of November 1st, 2016, the Ploiesti Court of Appeal ruled as correct the decision of the Damboviţa Bar's Council to exclude the female plaintiff from the lawyer's profession, as she had been sentenced through the penal ruling no. 80 of July $19^{\text {th }}, 2013$ - for the offence of complicity to abuse of office against the interests of persons and for the offence of forged instrument by false signature - to three years of imprisonment. The female plaintiff had been convicted for corruption offences, which made her unworthy of exercising the lawyer's profession. The Bar's Council ruled on excluding her from the profession due to indignity, a totally different aspect from the additional punishment included in the criminal ruling prohibiting the exercise of the profession indefinitely. It was not relevant for the Court that certain lawyers convicted definitively for corruption offences had not been targeted by the decision of suspension or exclusion, given that such situations were to be appraised individually by the decision-making bodies. There is a small margin of appreciation concerning the "analysis" of the criminal ruling, in order to determine whether the offence targeted by the criminal law for which the person was convicted made the person in question unworthy of being a lawyer. Through the penal ruling no. 3848 of June $30^{\text {th }}, 2016$, the Bucharest Court of Appeal maintains the criminal ruling no. 7330 of October $28^{\text {th }}, 2015$, of the Bucharest Court and rules that there is a definitive conviction to imprisonment for a wilful offence and that such conviction makes the person unworthy of exercising the lawyer's profession. It is irrelevant that the offences of influence peddling were not committed within the exercise of the profession and that the criminal court did not prohibit the exercise of the profession, given that the legislator failed to mention such circumstances in the procedure of exclusion from the Bar. The measure of ceasing the lawyer's capacity is necessary in the case of a definitive imprisonment sentence, for a wilful offence. Through the Decision no. 1165 of April 6 ${ }^{\text {th }}, 2016$, the Bucharest Court of Appeal rules that such a

CONSTITUTIONAL LAW REVIEW 
to preserve in the profession or to cease the lawyer's capacity. The Decision of the Bar's Council is motivated and notified as soon as possible to the lawyer in question, as well as to the president of the National Association of the Romanian Bars, along with the court's decision and the documents based on which the indignity state was assessed. The Decision of ceasing the lawyer's profession is executory, but it may be appealed by the president of the National Association of the Romanian Bars and/or by the lawyer in question, within 15 days from the notification, at the National Association of the Romanian Bars's Council. The cease of the lawyer's capacity is a topic featured accordingly in the table of lawyers.

A legal standard characterised by clarity and precision will produce the effects for which it was created. The interpretation of the legal provisions in order to identify the legislator's will must circumscribe to the clear and precise character from which any legal standard should benefit. This is very much the purpose of the principle ubi lex non distinguit, nec nos distinguere debemus.

De lege ferenda, the special law should state expressly that it is unworthy that the person convicted definitively through a criminal ruling to imprisonment for committing a wilful offence for which the law states the sanction of reclusion for more than 3 years, for offences affecting or being tangential with customer relations, with other lawyers or with the professional bodies, offences concerning the unfolding of judiciary, jurisdictional or administrative procedures that may involve a lawyer.

The gravity of the offences for which lawyers are convicted must also be expressed at a repressive level from a professional perspective, in a harsher manner, taking into account precisely the prejudice brought against the socio-professional relations entailed by their lawyer's capacity. Some acts committed by lawyers inherently create and induce the idea - highly dangerous for the balance of social relationships as a whole - of promoting interests using ominous paths, not abiding the law, by buying up favours from the judges ruling on a criminal matter.

Society gives to lawyers a crucial role, the confidence in their professional activity is inherent to the trust in the justice system of people arriving before a court. Furthermore, lawyers - pursuant to their capacity - should enjoy spotless moral probity. A lawyer's mission also includes the supervision of law observance. Honour, equity, dignity, loyalty, probity, conscience, correctness and justice spirit are essential principles of the lawyer's profession statute. However, some lawyers do not only ignore these basic principles of the lawyer's profession, but they have also converted the role of law protectors into one of eluding the legal provisions, thus compromising the reputation of this profession and the public confidence in the lawyer's profession.

criminal behaviour from the plaintiff has led to the measure of ceasing her lawyer's capacity and of removing her from the table of lawyers. She still has the possibility of carrying out activities in other fields, which would allow her to exercise a profession even in the event of a criminal conviction, as a jurist or as something else in the same field. 

